Correspondence

Margarita L. Miroshnichenko alfamirr@mail.ru

\section{Caldimicrobium rimae gen. nov., sp. nov., an extremely thermophilic, facultatively lithoautotrophic, anaerobic bacterium from the Uzon Caldera, Kamchatka}

\author{
Margarita L. Miroshnichenko, ${ }^{1}$ Alexander V. Lebedinsky, ${ }^{1}$ N. A. Chernyh, ${ }^{1}$ \\ Tatyana P. Tourova, ${ }^{1}$ Tatyana V. Kolganova, ${ }^{2}$ Stefan Spring ${ }^{3}$ \\ and Elizaveta A. Bonch-Osmolovskaya ${ }^{1}$
${ }^{1}$ Winogradsky Institute of Microbiology, Russian Academy of Sciences, Prospect 60-Letiya Oktyabrya 7/2, 117312 Moscow, Russia
${ }^{2}$ Bioengineering Center, Russian Academy of Sciences, Prospect 60-Letiya Oktyabrya 7/1, 117312 Moscow, Russia
${ }^{3}$ DSMZ - German Collection of Microorganisms and Cell Cultures, Inhoffenstraße 7B, 38124 \\ Braunschweig, Germany
}

\begin{abstract}
An extremely thermophilic, strictly anaerobic, facultatively chemolithoautotrophic bacterium designated strain DS ${ }^{\top}$ was isolated from Treshchinnyi Spring, one of the hottest springs of the Uzon Caldera (Kamchatka, Russia). Cells of the novel organism were Gram-negative rods, about 1.0-1.2 $\mu \mathrm{m}$ long and $0.5 \mu \mathrm{m}$ wide. The temperature range for growth was $52-82{ }^{\circ} \mathrm{C}$, with an optimum at $75{ }^{\circ} \mathrm{C}$. Growth was observed at $\mathrm{pH}$ 6.8-7.4, and the optimum $\mathrm{pH}$ was 7.0-7.2. Strain $\mathrm{DS}^{\top}$ was able to grow lithoautotrophically with hydrogen in the presence of $\mathrm{CO}_{2}$ as a carbon source and thiosulfate or elemental sulfur as an electron acceptor. It also grew well with ethanol, fumarate, succinate or malate in the presence of thiosulfate. Yeast extract was not required for growth and did not stimulate growth. The genomic DNA $\mathrm{G}+\mathrm{C}$ content was $35.2 \mathrm{~mol} \%$. Phylogenetic analysis of the 16S rRNA gene sequence indicated that the novel organism was a member of the family Thermodesulfobacteriaceae. On the basis of phylogenetic and physiological considerations, it is proposed that strain $D S^{\top}$ represents a new genus and species, Caldimicrobium rimae gen. nov., sp. nov. The type strain of Caldimicrobium rimae is $\mathrm{DS}^{\top}$ $\left(=\right.$ DSM $19393^{\top}=$ VKM B-2460 $)$.
\end{abstract}

The phylum 'Thermodesulfobacteria' (Garrity \& Holt, 2001) represents one of the deeply branching lineages within the domain Bacteria and comprises Gram-negative, rodshaped, anaerobic, thermophilic, sulfate-reducing microorganisms. At present, the phylum includes a single class Thermodesulfobacteria, a single order Thermodesulfobacteriales and a single family Thermodesulfobacteriaceae, consisting of the genera Thermodesulfobacterium (Zeikus et al., 1983) and Thermodesulfatator (Moussard et al., 2004) with validly published names and the genus 'Geothermobacterium' (Kashefi et al., 2002), which as yet has no standing in nomenclature. The group of microorganisms belonging to the family Thermodesulfobacteriaceae is metabolically diverse and includes both

The GenBank/EMBL/DDBJ accession number for the 16S rRNA gene sequence of strain $D^{\top}{ }^{\top}$ is EF554596.

A maximum-parsimony tree based on $16 \mathrm{~S}$ rRNA gene sequences is available as supplementary material with the online version of this paper. obligate chemolithotrophs (Jeanthon et al., 2002; Kashefi et al., 2002; Moussard et al., 2004) and chemo-organotrophs (Zeikus et al., 1983; Rosanova \& Pivovarova, 1988; Sonne-Hansen \& Ahring, 1999). All of them, except the obligate iron-reducer 'Geothermobacterium ferrireducens', are able to reduce sulfate. In this paper, we report the isolation and characterization of a novel extremely thermophilic, anaerobic, facultatively lithoautotrophic bacterium that belongs to the family Thermodesulfobacteriaceae and, similarly to ' $G$. ferrireducens', is not capable of dissimilatory sulfate reduction.

A sample of sediment mixed with water was collected from Treshchinnyi ('Crack') Spring in the eastern solfataric field of the Uzon Caldera. The temperature and $\mathrm{pH}$ of the water at the sampling site were $80{ }^{\circ} \mathrm{C}$ and $\mathrm{pH}$ 6.3. For the initial enrichment, the following basal medium was used $\left(\mathrm{l}^{-1}\right)$ : $\mathrm{NH}_{4} \mathrm{Cl}, 0.33 \mathrm{~g} ; \mathrm{MgCl}_{2} \cdot 6 \mathrm{H}_{2} \mathrm{O}, 0.33 \mathrm{~g} ; \mathrm{CaCl}_{2} \cdot 6 \mathrm{H}_{2} \mathrm{O}, 0.1 \mathrm{~g}$; $\mathrm{KCl}, 0.33 \mathrm{~g} ; \mathrm{KH}_{2} \mathrm{PO}_{4}, 0.33 \mathrm{~g}$; resazurin, $0.001 \mathrm{~g}$; trace- 
element solution (Pfennig \& Lippert, 1966), $1 \mathrm{ml}$; and vitamin solution (Wolin et al., 1963), $1 \mathrm{ml}$. After being boiled, the medium was cooled under $\mathrm{CO}_{2}$ and supplemented with $2.0 \mathrm{~g} \mathrm{Na}_{2} \mathrm{~S}_{2} \mathrm{O}_{3}, 1.5 \mathrm{~g} \mathrm{NaHCO}_{3}$ and $0.5 \mathrm{~g}$ $\mathrm{Na}_{2} \mathrm{~S} .9 \mathrm{H}_{2} \mathrm{O} \mathrm{l}^{-1}$. $\mathrm{NaOH}\left(6 \mathrm{ml}\right.$ of a $10 \%$ solution $\left.\mathrm{l}^{-1}\right)$ was added to the medium before autoclaving to adjust the $\mathrm{pH}$ to 7.2. The medium was dispensed in $5 \mathrm{ml}$ portions into $20 \mathrm{ml}$ Balch tubes and the headspace was filled with $100 \%$ $\mathrm{H}_{2}$ at atmospheric pressure. After autoclaving, the tubes were inoculated with a mixture of water and sediment and incubated at $82{ }^{\circ} \mathrm{C}$. After 5 days of incubation, the growth of small, oval rods was observed. Growth was accompanied by formation of sulfide, determined as described by Trüper \& Schlegel (1964). The culture was purified using the dilution-to-extinction technique and designated strain $\mathrm{DS}^{\mathrm{T}}$. Electron microscopy (Bonch-Osmolovskaya et al., 1990) indicated that cells of isolate $\mathrm{DS}^{\mathrm{T}}$ were small rods, about $1-1.2 \mu \mathrm{m}$ long and $0.5 \mu \mathrm{m}$ wide, with two polar flagella (Fig. 1a). They occurred singly or formed chains of varying length (up to eight cells). Electron micrographs of thin sections of cells revealed that the cell-wall structure was typical of Gram-negative bacteria (Fig. 1b).

After demonstrating that strain $\mathrm{DS}^{\mathrm{T}}$ grew well with fumarate $(10 \mathrm{mM})$ and thiosulfate $(10 \mathrm{mM})$, we chose this donor-acceptor pair for growth experiments. In this case, the headspace of the tubes was filled with $100 \% \mathrm{CO}_{2}$. The cell density was determined by direct cell counting. The $\mathrm{pH}$ range for growth was determined using various buffers (MES for $\mathrm{pH}$ 6.0-6.5, PIPES for $\mathrm{pH}$ 6.5-7.0, HEPES for $\mathrm{pH} 7.0-7.5$ and Tris for $\mathrm{pH} 7.5-8.0$ ) at a concentration of $10 \mathrm{mM}$. $\mathrm{NaHCO}_{3}$ was omitted from the medium. The $\mathrm{pH}$ was determined at room temperature. Strain $\mathrm{DS}^{\mathrm{T}}$ was a neutrophilic bacterium, growing in a $\mathrm{pH}$ range of $6.8-7.4$ with an optimum at $\mathrm{pH} 7.0-7.2$; no growth was detected at $\mathrm{pH} 7.5$ or 6.5 . The novel isolate grew at $52-82{ }^{\circ} \mathrm{C}$ with an optimum at $75{ }^{\circ} \mathrm{C}$; no growth was detected at 85 or $50{ }^{\circ} \mathrm{C}$. The doubling time under optimum growth conditions was about $4 \mathrm{~h}$. The final cell concentration under optimal growth conditions was $3.2 \times 10^{7}$ cells $\mathrm{ml}^{-1}$.
Strain $\mathrm{DS}^{\mathrm{T}}$ was a strictly anaerobic organism. It was able to grow lithoautotrophically with hydrogen in the presence of $\mathrm{CO}_{2}$ as a carbon source, ammonium as the source of nitrogen and thiosulfate or elemental sulfur as the electron acceptor. It grew well with ethanol, fumarate, succinate or malate in the presence of thiosulfate. Compounds tested but not utilized as electron donors by strain $\mathrm{DS}^{\mathrm{T}}$ were acetate, propionate, glucose, sucrose, galactose, lactate, pyruvate (all at $20 \mathrm{mM})$, methanol $(10 \mathrm{mM})$, starch, yeast extract and peptone (all at $10 \mathrm{~g} \mathrm{l}^{-1}$ ). In the presence of hydrogen, fumarate or ethanol, strain $\mathrm{DS}^{\mathrm{T}}$ could use elemental sulfur $\left(10 \mathrm{~g} \mathrm{l}^{-1}\right)$ as an alternative electron acceptor; however, the cell yield was lower than that with thiosulfate. Nitrate $(10 \mathrm{mM})$, sulfate $(10 \mathrm{mM})$, sulfite $(2 \mathrm{mM})$, nitrite $(2 \mathrm{mM})$, amorphous $\mathrm{Fe}(\mathrm{III})$ oxide $(90 \mathrm{mM})$ (Slobodkin et al., 1999) and $\mathrm{Fe}(\mathrm{III})$ citrate $(20 \mathrm{mM})$ were not used as electron acceptors. Pyruvate, lactate and fumarate were not fermented. The end product of anaerobic respiration with thiosulfate or sulfur was $\mathrm{H}_{2} \mathrm{~S}$. Yeast extract $\left(100 \mathrm{mg} \mathrm{l}^{-}\right)$was not required for growth of strain $\mathrm{DS}^{\mathrm{T}}$ and, when added, did not stimulate growth.

DNA was isolated as described by Marmur (1961). The DNA $\mathrm{G}+\mathrm{C}$ content was $35.2 \mathrm{~mol} \%$ as determined by melting point analysis (Marmur \& Doty, 1962), using Escherichia coli K-12 DNA as a reference. For amplification and sequencing of the 16S rRNA gene, DNA was obtained by standard phenol/chloroform extraction. The 16S rRNA gene was selectively amplified using 5'-AGAGTTGATCCTGGCTCAG-3' and 5'-TACGGTTACCTTGTTACGACTT- $3^{\prime}$ as the forward and reverse primers, respectively. PCR products were purified using the Wizard PCR-Prep kit (Promega) according to the manufacturer's instructions. Sequencing was performed using a Big Dye Terminator v.3.1 sequencing reaction kit and an ABI 3730 DNA automatic sequencer (Applied Biosystems). In various phylogenetic trees that were reconstructed by using either maximum-likelihood, neighbour-joining or parsimony methods, the novel isolate $\mathrm{DS}^{\mathrm{T}}$ formed a distinct branch within the family Thermodesulfobacteriaceae, thereby confirming its separate taxonomic status. A
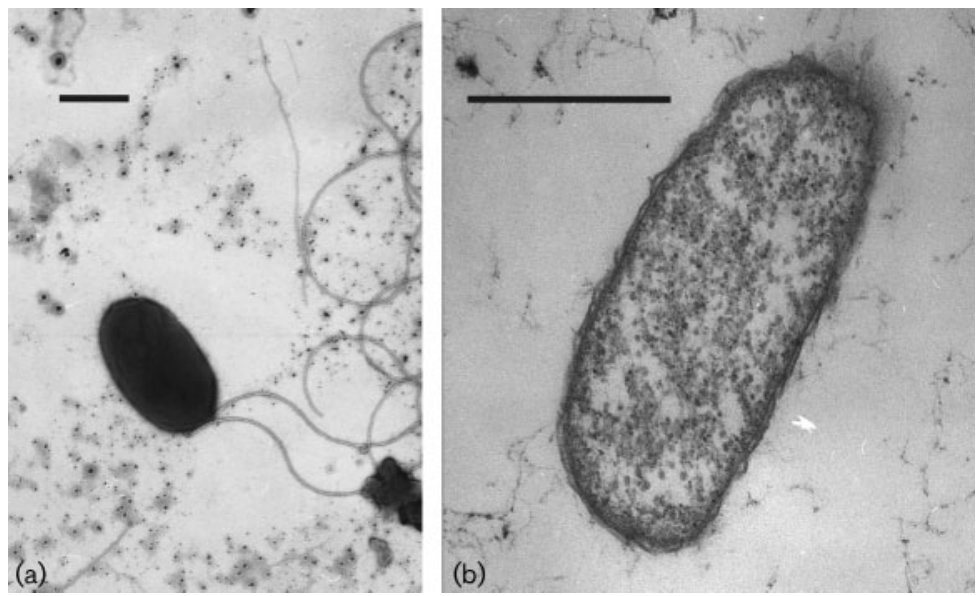

Fig. 1. Electron micrographs of cells of strain $\mathrm{DS}^{\top}$ showing a negatively stained whole cell (a) and a cell thin section (b). Bars, $0.5 \mu \mathrm{m}$. 
representative maximum-likelihood tree is shown in Fig. 2 and a parsimony tree containing bootstrap values (1000 resamplings) is shown in Supplementary Fig. S1 (available in IJSEM Online).

The phylogenetic affiliation of strain $\mathrm{DS}^{\mathrm{T}}$ was examined according to the method described by Vatsurina et al. (2008). 'G. ferrireducens' FW-1a was the most closely related strain to strain $\mathrm{DS}^{\mathrm{T}}$, with $97.0 \% 16 \mathrm{~S}$ rRNA gene sequence similarity. 'G. ferrireducens' is the only species of this genus and the name has not yet been validly published. Strain DS ${ }^{\mathrm{T}}$ differs significantly from ' $G$. ferrireducens' in the temperature characteristics of growth and the electron acceptors and donors used (Table 1). 'G. ferrireducens' is an obligate $\mathrm{Fe}(\mathrm{III})$-reducer, gaining energy exclusively by hydrogen oxidation and formation of magnetite as the end product. Strain $\mathrm{DS}^{\mathrm{T}}$ is nutritionally more versatile: it is able to use ethanol and some non-fermentable electron donors in the presence of thiosulfate. In addition, the novel isolate is unable to utilize crystalline $\mathrm{Fe}$ (III) oxides and, hence, it is clearly distinguishable from ' $G$. ferrireducens' (Table 1). Based on phylogenetic considerations, strain DS ${ }^{\mathrm{T}}$ is also related to the species of the genus Thermodesulfobacterium: Thermodesulfobacterium hydrogeniphilum (95.8\% 16S rRNA gene sequence similarity to the type strain), Thermodesulfobacterium commune (95.0\%), Thermodesulfobacterium hveragerdense (93.9\%) and Thermodesulfobacterium thermophilum (93.7\%). Of these species, Thermodesulfobacterium hydrogeniphilum is the only one able to grow autotrophically with hydrogen in the presence of sulfate. However, strain $\mathrm{DS}^{\mathrm{T}}$ does not exhibit the ability to reduce sulfate, which is the most important common characteristic of all members of the genus Thermodesulfobacterium. Other distinctions between strain $\mathrm{DS}^{\mathrm{T}}$ and related species are presented in Table 1.

A characteristic feature of isolate $\mathrm{DS}^{\mathrm{T}}$ is its ability to use elemental sulfur as an electron acceptor in the course of growth. This capacity is an intrinsic metabolic feature of micro-organisms of the family Desulfurobacteriaceae and the genus Thermosulfidibacter (L'Haridon et al., 2006; Nunoura et al., 2008). These organisms are anaerobic, thermophilic, highly specialized hydrogen-oxidizers that readily reduce $S^{0}$; for members of Thermosulfidibacter, sulfur is the sole electron acceptor. In contrast to strain $\mathrm{DS}^{\mathrm{T}}$, they are unable to oxidize organic acids or alcohols and cannot use thiosulfate as an electron acceptor. Phylogenetically, isolate $\mathrm{DS}^{\mathrm{T}}$ is remote from the family Desulfurobacteriaceae and the genus Thermosulfidibacter (the 16S rRNA gene sequence similarity is about $85 \%$ ).

In various phylogenetic trees that were reconstructed by using either maximum-likelihood, neighbour-joining or parsimony methods, the novel isolate $\mathrm{DS}^{\mathrm{T}}$ formed a distinct branch within the family Thermodesulfobacteriaceae, thereby confirming its separate taxonomic status (Fig. 2; Supplementary Fig. S1).

On the basis of physiological traits in combination with the results of the 16S rRNA gene sequence comparison, we propose that strain $\mathrm{DS}^{\mathrm{T}}$ should be assigned to a new genus and species within the family Thermodesulfobacteriaceae, for which we propose the name Caldimicrobium rimae gen. nov., sp. nov.

\section{Description of Caldimicrobium gen. nov.}

Caldimicrobium (Cal.di.mi.cro'bi.um. L. adj. caldus hot; N.L. neut. n. microbium microbe; N.L. neut. n. Caldimicrobium microbe living in hot places).

Extremely thermophilic. Strictly anaerobic. Cells are Gramnegative, oval rods, about $1.0-1.2 \mu \mathrm{m}$ long and $0.5 \mu \mathrm{m}$ wide, with two polar flagella. Neutrophilic. Able to grow chemolithoautotrophically with molecular hydrogen in the presence of thiosulfate or elemental sulfur with formation of $\mathrm{H}_{2} \mathrm{~S}$. Able to utilize organic acids and alcohols in the presence of the same electron acceptors. The DNA G $+\mathrm{C}$ content of the type strain of the type species is $35.2 \mathrm{~mol} \%$. $16 \mathrm{~S}$ rRNA gene sequence analysis places the genus in the family Thermodesulfobacteriaceae. The type species is Caldimicrobium rimae.

\section{Description of Caldimicrobium rimae sp. nov.}

Caldimicrobium rimae (ri'mae. L. gen. n. rimae of a crack or fissure, referring to the English translation of Treshchinnyi, the hot spring from which the type strain was isolated).

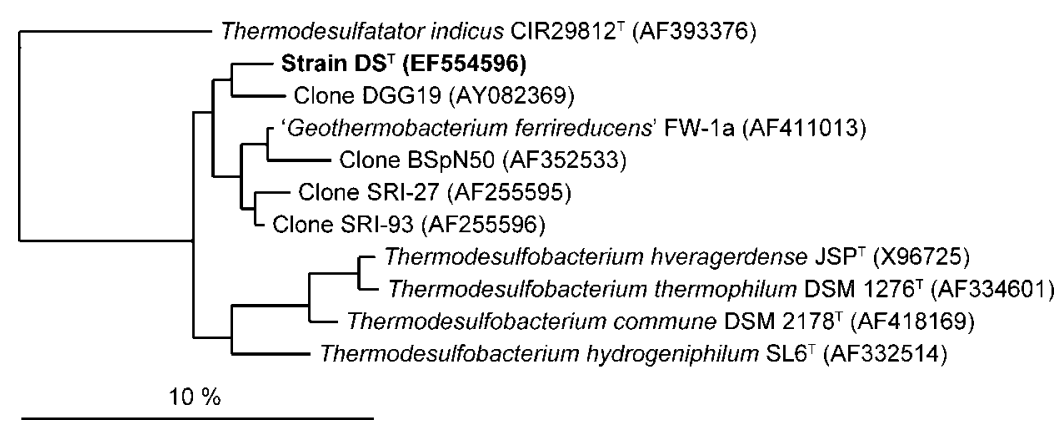

Fig. 2. Phylogenetic tree based on an alignment of almost-complete 16S rRNA gene sequences, showing the affiliation of strain $\mathrm{DS}^{\top}$ to the family Thermodesulfobacteriaceae. GenBank/EMBL/ DDBJ accession numbers are shown in parentheses. The tree was reconstructed using the fastDNAml algorithm included in the ARB program package version 03_08_22 (http://www.arbhome.de). The sequence of Desulfovibrio desulfuricans ATCC 27774 (GenBank accession no. M34113; not shown) was used to define the root. Bar, $10 \%$ estimated sequence divergence. 
Table 1. Characteristics that differentiate strain $D S^{\top}$ from members of the family Thermodesulfobacteriaceae

Reference species: 1, 'Geothermobacterium ferrireducens' (data from Kashefi et al., 2002); 2, Thermodesulfobacterium hydrogeniphilum (Jeanthon et al., 2002); 3, Thermodesulfobacterium hveragerdense (Sonne-Hansen \& Ahring, 1999); 4, Thermodesulfobacterium commune (Zeikus et al., 1983); 5, Thermodesulfobacterium thermophilum (Rosanova \& Pivovarova, 1988); 6, Thermodesulfatator indicus (Moussard et al., 2004). NR, Not reported.

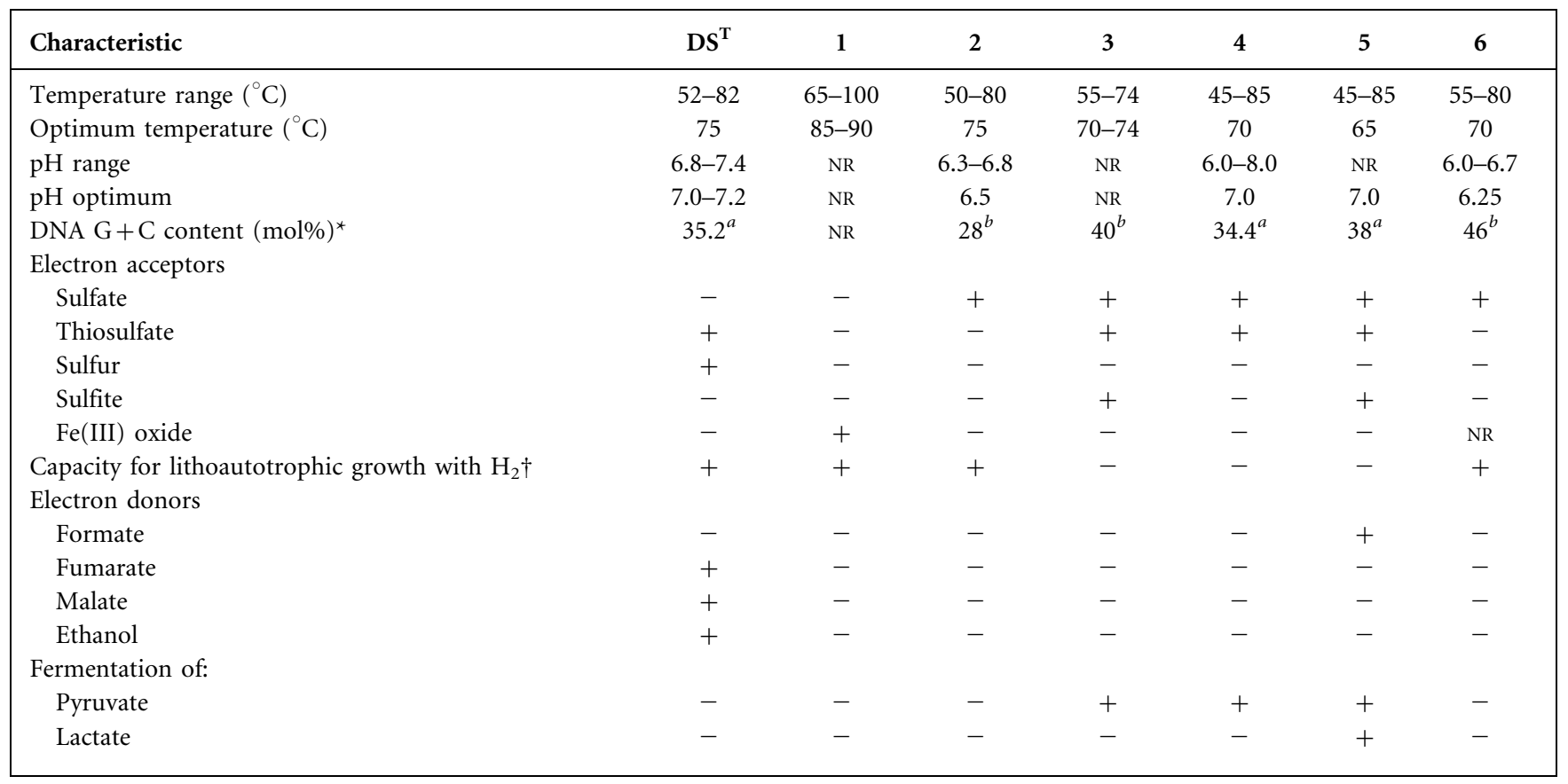

${ }^{\star}$ Determined by: $a$, melting-point analysis; $b$, HPLC.

$\dagger$ Growth with hydrogen in the presence of an organic carbon source.

Displays the following characteristics in addition to those given for the genus. Growth occurs at $52-82{ }^{\circ} \mathrm{C}$, with an optimum at $75^{\circ} \mathrm{C}$; the $\mathrm{pH}$ range for growth is $\mathrm{pH}$ 6.8-7.4, with an optimum at $\mathrm{pH} 7.0-7.2$. Grows chemoorganotrophically with ethanol, fumarate, malate or succinate.

The type strain, $\mathrm{DS}^{\mathrm{T}}\left(=\mathrm{DSM} 19393^{\mathrm{T}}=\mathrm{VKM} \mathrm{B}-2460^{\mathrm{T}}\right)$, was isolated from the terrestrial neutral hot spring Treshchinnyi, located in the Uzon Caldera, Kamchatka, Russia.

\section{Acknowledgements}

We thank Alexander Slobodkin for testing the new strain for ironreduction ability. This work was supported by programs of the Russian Academy of Sciences 'Molecular and Cell Biology' and 'Origin and Evolution of the Biosphere' and by the Russian Foundation for Basic Research grant 06-04-49-045.

\section{References}

Bonch-Osmolovskaya, E. A., Sokolova, T. G., Kostrikina, N. A. \& Zavarzin, G. A. (1990). Desulfurella acetivorans gen. nov., sp. nov. - a new thermophilic sulfur-reducing eubacterium. Arch Microbiol 153, $151-155$.

Garrity, G. M. \& Holt, J. G. (2001). Phylum BIII. Thermodesulfobacteria phy. nov. In Bergey's Manual of Systematic Bacteriology, 2nd edn, vol. 1, p. 389. Edited by D. R. Boone, R. W. Castenholz \& G. M. Garrity. New York: Springer.

Jeanthon, C., L'Haridon, S., Cueff, V., Banta, A., Reysenbach, A.-L. \& Prieur, D. (2002). Thermodesulfobacterium hydrogeniphilum sp. nov., a thermophilic, chemolithoautotrophic, sulfate-reducing bacterium isolated from a deep-sea hydrothermal vent at Guaymas Basin, and emendation of the genus Thermodesulfobacterium. Int J Syst Evol Microbiol 52, 765-772.

Kashefi, K., Holmes, D. E., Reysenbach, A.-L. \& Lovley, D. R. (2002). Use of $\mathrm{Fe}(\mathrm{III})$ as an electron acceptor to recover previously uncultured hyperthermophiles: isolation and characterization of Geothermobacterium ferrireducens gen. nov., sp. nov. Appl Environ Microbiol 68, 1735-1742.

L'Haridon, S., Reysenbach, A.-L., Tindall, B. J., Schönheit, P., Banta, A., Johnsen, U., Schumann, P., Gambacorta, A., Stackebrandt, E. \& Jeanthon, C. (2006). Desulfurobacterium atlanticum sp. nov., Desulfurobacterium pacificum sp. nov. and Thermovibrio guaymasensis sp. nov., three thermophilic members of the Desulfurobacteriaceae fam. nov., a deep branching lineage within the Bacteria. Int J Syst Evol Microbiol 56, 2843-2852.

Marmur, J. (1961). A procedure for the isolation of deoxyribonucleic acid from microorganisms. J Mol Biol 3, 208-218.

Marmur, J. \& Doty, D. (1962). Determination of the base composition of deoxyribonucleic acid from its thermal denaturation temperature. J Mol Biol 5, 109-118.

Moussard, H., L'Haridon, S., Tindall, B. J., Banta, A., Schumann, P., Stackebrandt, E., Reysenbach, A.-L. \& Jeanthon, C. (2004). Thermodesulfatator indicus gen. nov., sp. nov., a novel thermophilic 
chemolithotrophic sulfate-reducing bacterium isolated from the Central Indian Ridge. Int J Syst Evol Microbiol 54, 227-233.

Nunoura, T., Oida, H., Misavuki, M. \& Suzuki, Y. (2008). Thermosulfidibacter takaii gen. nov., sp. nov., a thermophilic, hydrogen-oxidizing, sulfur-reducing bacterium isolated from a deep-sea hydrothermal field in the Southern Okinawa Trough. Int $J$ Syst Evol Microbiol 58, 659-665.

Pfennig, N. \& Lippert, K. D. (1966). Über das Vitamin $\mathrm{B}_{12}$-Bedürfnis phototropher Schwefelbacterien. Arch Microbiol 55, 245-256 (in German).

Rosanova, E. P. \& Pivovarova, T. A. (1988). Reclassification of Desulfovibrio thermophilus (Rosanova and Khudyakova, 1974). Microbiology (English translation of Mikrobiologiia) 57, 102-106.

Slobodkin, A. I., Tourova, T. P., Kuznetsov, B. B., Kostrikina, N. A., Chernyh, N. A. \& Bonch-Osmolovskaya, E. A. (1999). Thermoanaerobacter siderophilus sp. nov., a novel dissimilatory $\mathrm{Fe}$ (III)-reducing, anaerobic, thermophilic bacterium. Int $J$ Syst Bacteriol 49, 1471-1478.
Sonne-Hansen, J. \& Ahring, B. K. (1999). Thermodesulfobacterium hveragerdense sp. nov and Thermodesulfovibrio islandicus sp. nov., two thermophilic sulfate reducing bacteria isolated from a Icelandic hot spring. Syst Appl Microbiol 22, 559-564.

Trüper, H. G. \& Schlegel, H. G. (1964). Sulfur metabolism in Thiorhodaceae. I. Quantitative measurements on growing cells of Chromatium okenii. Antonie van Leeuwenhoek 30, 225-238.

Vatsurina, A., Badrutdinova, D., Schumann, P., Spring, S. \& Vainshtein, M. (2008). Desulfosporosinus hippei sp. nov., a mesophilic sulfate-reducing bacterium isolated from permafrost. Int J Syst Evol Microbiol 58, 1228-1232.

Wolin, E. A., Wolin, M. J. \& Wolfe, R. S. (1963). Formation of methane by bacterial extracts. J Biol Chem 238, 2882-2886.

Zeikus, J. G., Dawson, M. A., Thompson, T. E., Ingvorsen, K. \& Hatchikian, E. C. (1983). Microbial ecology of volcanic sulphidogenesis: isolation and characterization of Thermodesulfobacterium commune gen. nov and sp. nov. J Gen Microbiol 129, 1159-1169. 